\title{
Unleashing endogenous TNF-alpha as a cancer immunotherapeutic
}

\author{
Steven F. Josephs ${ }^{1}$, Thomas E. Ichim² ${ }^{2}$ Stephen M. Prince ${ }^{1 *}$, Santosh Kesari ${ }^{3}$, Francesco M. Marincola ${ }^{1}$, \\ Anton Rolando Escobedo ${ }^{4}$ and Amir Jafri ${ }^{1}$
}

\begin{abstract}
Tumor necrosis factor (TNF)-alpha was originally identified in the 1970s as the serum mediator of innate immunity capable of inducing hemorrhagic necrosis in tumors. Today, a wide spectrum of biological activities have been attributed to this molecule, and clinical translation has mainly occurred not in using it to treat cancer, but rather to inhibit its effects to treat autoimmunity. Clinical trials utilizing systemic TNF-alpha administration have resulted in an unacceptable level of toxicities, which blocked its development. In contrast, localized administration of TNF-alpha in the form of isolated limb perfusion have yielded excellent results in soft tissue sarcomas. Here we describe a novel approach to leveraging the potent antineoplastic activities of TNF-alpha by enhancing activity of locally produced TNF-alpha through extracorporeal removal of soluble TNF-alpha receptors. Specifically, it is known that cancerous tissues are infiltrated with monocytes, T cells, and other cells capable of producing TNF-alpha. It is also known that tumors, as well as cells in the tumor microenvironment produce soluble TNF-alpha receptors. The authors believe that by selectively removing soluble TNF-alpha receptors local enhancement of endogenous TNF-alpha activity may provide for enhanced tumor cell death without associated systemic toxicities.
\end{abstract}

Keywords: Immunotherapy, TNF-alpha, Extracorporeal, Soluble TNF-alpha receptors, Cancer, Immuno-oncology

\section{Background}

The history of TNF-alpha is very closely related to the history of tumor immunotherapy. In the early 1900s, the New York physician William Coley observed that various cancer patients would enter remission after experiencing bacterial infections. In a brave set of experiments, Dr. Coley began emulating bacterial infections by purposely administering various combinations of pathogens to patients. One of these mixtures, containing Streptococcus pyogenes and Serratia marcescens, was demonstrated to possess therapeutic activity and became widely used in the USA prior to the advent of chemotherapy and radiotherapy. Today, such "Coley's toxins" are limited due to lack of controlled clinical trials and FDA approvals. In the 1960s, attempts to identify the molecular mechanisms by which Serratia marcescens induced tumor regression led to the discovery of a "factor" in the sera of treated

*Correspondence: steve.prince@immunicom.com

${ }^{1}$ Immunicom, Inc., San Diego, CA, USA

Full list of author information is available at the end of the article mice [1]. This factor was identified in 1975 as "Tumor Necrosis Factor" (TNF-alpha) [2]. It was found that this endotoxin induced factor, was also inducible with known immune stimulants such as bacillus Calmette-Guerin (BCG), zymosan, and Corynebacteria. The isolated factor had the capability to directly kill tumor cells in vitro, but there were no deleterious effects on proliferating nonmalignant murine embryonic cells.

Molecular analysis led to cloning of the cDNA and revealed the molecule was comprised of 233 amino acids with a leader sequence of the first 76 amino acids $[3,4]$. Interestingly, it was found that the same sequence belonged to another factor associated with cancer: Cachectin [5]. Cachectin was originally demonstrated to mediate weight loss and alter normal metabolic priorities through its effects on both the central nervous system (CNS) and peripheral tissues. Early studies showed that administration of cachectin in animals induces cachexia with a pattern of tissue wasting that includes whole-body protein depletion, unlike the protein-conserving pattern induced by simple caloric restriction [6, 7]. Given 
the inflammatory nature of TNF-alpha, studies where performed to assess its role in endotoxin-induced shock models.

It was found that administration of TNF-alpha in quantities approximating endogenous levels that were observed in response to endotoxin resulted in hypotension, metabolic acidosis, hemoconcentration, and death due to respiratory arrest within minutes to hours. This sequence resembled sepsis associated symptomology. Hyperglycemia and hyperkalemia were also observed after infusion. At necropsy, diffuse pulmonary inflammation and hemorrhage were apparent on gross and histopathologic examination, along with ischemic and hemorrhagic lesions of the gastrointestinal tract, and acute renal tubular necrosis [8-11]. Thus TNF-alpha, appeared to not only be a potent mediator of tumor regression, but also an effector of cachexia, and a contributor to one of the main mechanisms leading to septic shock.

\section{TNF-alpha forms and family}

TNF-alpha is found in a soluble and membrane bound form. The soluble plasma form of TNF-alpha is cleaved from the membrane forms by a metalloproteinase termed TNF-alpha-converting enzyme (TACE) which belongs to the ADAMs family of disintegrins $[12,13]$. Soluble TNFalpha is $17-\mathrm{kDa}$ protein consisting of 157 amino acids that forms a homotrimer for receptor activation. TNFalpha is mainly produced by activated macrophages, $\mathrm{T}$ lymphocytes, and natural killer (NK) cells [14]. A related but distinct cytokine, TNF-beta, previously known as Lymphotoxin was characterized to share some of the activity of TNF-alpha [15-17]. At present count, there are 19 members of the TNF family and 29 receptors that have been characterized [18-20].

\section{TNF-alpha receptors 1 and 2}

The activity of TNF-alpha is mediated through two cell surface receptors, TNF-R1 (p55) and TNF-R2 (p75) that differ in their signaling activity. TNF-R1 is usually proapoptotic whereas TNF-R2 is usually anti-apoptotic [21]. TNF-R1 and TNF-R2 have similar extracellular TNF-binding structures characterized by four repeated cysteine-rich domains but have different intracellular domains [22]. The main structural difference between TNF-R1 and TNF-R2 that accounts for their divergent biological activity resides in that TNF-R2 lacks an intracellular death domain. Thus, in many systems, TNFalpha promotes apoptosis through activating TNF-R1 but causes pro-survival signaling through TNF-R2 [23-28]. After binding TNF-alpha, TNF-R1 recruits the adaptor protein TNF-R1-associated death domain protein (TRADD) and its downstream caspases (i.e.
Caspase 8) causing apoptosis [18, 29, 30]. Conversely, when TNF-alpha activates TNF-R2, recruitment of the TNF receptor-associated factors (TRAF2) occurs, resulting in stimulation of NF-kappa B, which possesses anti-apoptotic properties [19, 31]. TNF-R1 is the high affinity receptor which is internalized upon ligation whereas TNF-R2 is shed [32]. TNF-R2 is known to possess a higher affinity towards membrane bound TNFalpha as compared to soluble TNF-alpha [33].

While TNF-R1 is expressed on various tumor cells [34], and tumor endothelial cells [35], TNF-R2 is expressed on various immune cells including $\mathrm{T}$ regulatory cells [36, 37], myeloid suppressor cells [38], and some cancer cells $[39,40]$. That TNF-R1 receptor is mainly responsible for the toxicity is demonstrated by its reduction by treating with antisense TNF-R1 [41]. Tumor resistance to the cytotoxic effects of TNF-alpha is mediated by TNF-R2. For example, in the Lewis Lung Model, knock down of TNF-R2 in the cancer cells promotes robust anti-tumor effects upon administration of low dose murine TNF-alpha whereas in wild type mice it enhanced tumor growth while the TNF-R1 knockdown was not affected [42]. Moreover, TNF-R2 activation has been implicated in T-reg expansion and immune-suppression [28, 43].

\section{Role of TNF receptors in cancer}

The effects of systemically administered TNF-alpha are blocked by soluble receptors, sTNF-R1 and sTNF-R2, that are released into the plasma [44]. These are cleaved from the membrane forms by TACE (ADAM17) upon the introduction or release of soluble TNF-alpha [4547]. The receptor ligand affinity is largely dependent on the adaptor protein recruitment [48]. However TNFalpha mutants have been developed that specifically bind either TNF-R1 or TNF-R2 [49] and novel mutants have been obtained with lower toxicity and increased anti-tumor activity compared to wild type TNF-alpha [50].

The concentration of the soluble receptors increases following exposure to TNF that is produced after infections or upon administration of recombinant TNF as a function of the natural TNF buffering system to control runaway cytokine response [47]. These receptors have been found to be elevated in tumors and in the plasma of cancer patients [51] as a mechanism of tumor survival by counteracting the anti-cancer potential of TNF-alpha [52, 53]. Various complex interplays between receptors have been described based on vitro studies, which in some cases are contradictory. Accordingly, we will discuss below the cellular effects of TNF-alpha in various immunological and cancer systems. 


\section{Cellular effects of TNF-alpha}

Approximately $28 \%$ of cancers are susceptible to direct cell killing mediated by soluble TNF. The anti-tumor activity of TNF-alpha is now well established and can be mediated through a variety of mechanisms including: (1) Cellular apoptosis by binding to tumor cell surface receptors; (2) T-effector cell activation (macrophage and NK cells) by blocking T-Reg cells that are immune suppressors [54, 55]; (3) Inducing tumor microvasculature collapse through endothelial cell modulation and disruption of neoangiogenesis including disruption of tumor vasculature [56, 57]; (4) Promoting TAM (tumor associated macrophages) to M1 anti-tumor stage (see Fig. 1); (5) Attraction and stimulation of neutrophils and monocytes to sites of activation for anti-tumor immune responses $[58,59]$; and (6) Downregulation of IL-13 expression by eosinophilic-like cells and inhibition of tumor induced monocyte differentiation to immunosuppressive phenotypes [60].

As the most pleiotropic of cytokines, TNF-alpha contributes to both inflammation during infections and anti-inflammatory/tissue repair processes after clearance of infections [61]. Its effects at low levels of expression contribute to tumorigenesis [62]. Upon exposure to inflammatory stimuli, TNF-alpha as well as IL-1 and other chemokines are produced mainly by activated macrophages and other cells of the myeloid lineage which attracts and activates neutrophils and monocytes to the tumor site. In tumors, the membrane form of TNF-alpha on tumor cells interacts mainly with TNF-R2 to activate clearance of pro-tumor suppressor cells via the production of reactive oxygen intermediates with signaling through ceramide [63]. Consequently, intratumoral preservation of the membrane form (with lower intratumoral TACE activity) is associated with better prognosis [64]. Reverse signaling can also occur where the receptors

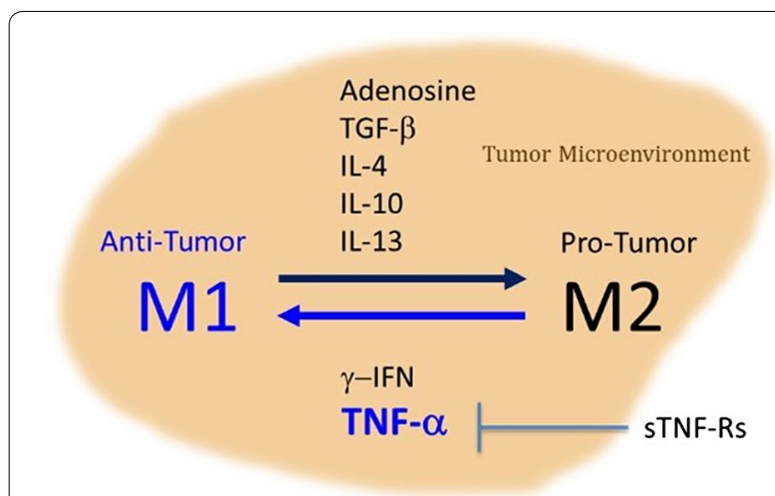

Fig. 1 Turning Cold Tumors Hot. TNF induces inflammation and anti-tumor M1. Soluble TNF receptors block the effects of TNF. Removal of sTNF-Rs unleashes TNF activity can activate intracellular processes after binding to the membrane form of TNF-alpha [65]. Neither TNF-alpha nor its receptors are lethal in murine knockout models. However, the organization of the lymphoid organs and thymus function are affected [66].

The anti-tumor effects of TNF-alpha have been demonstrated on primary tumors with significant pancancer effects through vascular destruction and tumor necrosis [56]. This effect is mainly attributable to TNF-R1 ligation. However, minimal residual disease (MRD) may be stimulated upon infections and lead to the development of resistance to cytotoxic drugs [67]. In a murine model, treatment with anti-TNF antibodies delays the onset of recurrence after initial complete regression of primary tumors. In attempt to control the potential pro-tumor effects of TNF-alpha, human clinical trials were conducted using anti-TNF antibodies or receptors and these have met with limited disease stabilization in approximately $20 \%$ of the patients [68-70]. However, induction of lymphoma or skin cancer was also observed [71, 72]. The ability to specifically block the anti-inflammatory/ tissue repair processes of TNF-alpha in MRD would be of significance with respect to controlling the recurrence of tumors. An elegant approach would be to identify methods with cytokine or drug combinations that induce long-term immune responses such as the combination of TNF and gamma Interferon [73]. Obviously, predicting outcomes will remain speculative until clinical trials are conducted.

\section{Potential for general anti-tumor therapy via vascular disruption by TNF}

Tumors can be categorized into three major types regarding their response to chemotherapy immune modulators: "hot", "cold" and "intermediate". Hot tumors contain a plethora of cell infiltrates whereas cold tumors have relatively few. Intermediate tumors are types that fall in between. Clinically, hot tumors tend to respond well to therapy, whereas cold tumors are resistant. Intermediate tumors may respond at first but then become resistant to therapy.

With few exceptions, tumors are dependent on neovascularization and in theory share a common susceptibility to TNF induced vascular disruption. In sufficient amounts, the global effect of TNF is predictably rapid, dependent on pertussis toxin G-protein inhibition and stimulation of the release of protein $S$ from the tumor endothelium to promote vascular modulation, and induces fibrin accumulation with clotting and enhancement of permeability leading to necrosis [74]. This effect is dependent on C5a complement factor [75]. Of interest is that specific delivery of TNF-alpha to tumor sites promotes anti-tumor effects [76, 77]. Overexpression of 
TNF in cancer cells results in longterm tumor growth suppression, independent of IL-12 or IL-18 and works via a STAT1 and IFN regulatory factor 1-dependent IFNgamma pathway [78]. Such higher-than-physiologic concentrations of TNF work through similar mechanisms in the normal vasculature leading to systemic toxicity. Factors in the tumor microenvironment contribute to the greater sensitivity of the tumor vasculature to TNF.

\section{Clinical trials of TNF-alpha for cancer therapy}

Initial clinical trials of TNF-alpha utilized systemic administration. Phase 1 studies all reported sepsis-associated symptoms as dose-limiting toxicities [79]. For example, Kimura et al. administered intravenous infusions starting at $1 \times 10$ [5] units $/ \mathrm{m}^{2}$ and escalated to $16 \times 10$ [5] units $/ \mathrm{m}^{2}$. Fever, rigors, nausea and vomiting, and anorexia toxicities where found to be non-dose-dependent; whereas hypotension, leukocytosis, thrombocytopenia and transient elevation of transaminases (SGOT and SGPT) where dose-dependent. Disseminated intravascular coagulopathy (DIC), a classical symptom of sepsis, was observed at the highest dose. The authors concluded that the maximum tolerated dose was $12 \times 10$ [5] units/ $\mathrm{m}^{2}$ [80]. Other studies found similar toxicities associated with systemic TNF-alpha administration, with little or no favorable achievement in tumor response [81-84]. Part of the cause of TNF-alphaassociated systemic toxicity is its ability to induce alterations to endothelial cells, resulting, in part, in augmentation of coagulopathy [85].

Given the inability to translate the profound anti-tumor effects observed in animal studies to human studies, some researchers have explored localized administration of TNF-alpha in hopes of avoiding adverse effects associated with systemic use. One of the first reports describing localized administration of TNF-alpha was Kahn et al. who treated 27 patients suffering from Kaposi's sarcoma. Intratumoral administration reduced the cross-sectional area in 15 of 16 injected cancer lesions and caused the complete disappearance of three lesions [86]. The noted high degree of vascularization in Kaposi's sarcoma may be one of the explanations for the high degree of success, given that TNF-alpha is known to induce vascular hemorrhage in malignant tissues [87-89]. Multiple mechanisms are believed to be associated with tumor vascular damage by TNF-alpha, including induction of release of von Willebrand Factor, which is a known anti-coagulant, as well as endothelial cell activation leading to thrombosis [90].

One clinically successful utilization of localized TNFalpha therapy is its use (usually in combination with the alkylating agent melphalan) in isolated limb perfusion (ILP) protocols. Early studies demonstrated synergy between TNF-alpha and melphalan in animal models of
ILP [91, 92]. These procedures have been translated to patients with melanoma and soft tissue sarcomas, where the complete response rate has been $80 \%$. It is believed that there are two mechanisms by which TNF-alpha functions as a contributor to such high response rates. The first involves augmentation of endothelium permeability, which facilitates entrance of chemotherapy, and the second mechanism involves direct killing of tumor endothelium, which results in vascular leakage. Hemorrhagic necrosis of tumors is observed in a rapid manner subsequent to TNF-alpha and melphalan administration, with disruption of cell-cell adhesive junctions occurring within minutes, followed by tumor vascular collapse $24 \mathrm{~h}$ later $[58,93]$. From a clinical perspective TNF-alpha ILP therapy was approved in Europe for high grade soft tissue sarcoma in 1998 [94].

Another clinical success of localized TNF-alpha administration is in liver metastasis where isolated hepatic perfusion (IHP) may be performed. IHP was first clinically applied almost 50 years ago [95] and offered the ability to locally administer high concentrations of chemotherapeutic agents without systemic toxicities. In extending IHP to TNF-alpha administration, one phase 2 trial at the Surgery Branch of the NCI, the overall response rate in 50 patients was reported at $74 \%$ and was observed across virtually all types of histologies treated. The response rates were maintained even in patients who had numerous metastases, large metastases, or who had a significant percentage of liver replaced by tumor. Overall the duration of response was 9 months, although in some patients it was more than 3 years [95]. To assess the contribution of TNF-alpha versus melphalan alone, 22 patients with ocular melanoma metastatic to liver were treated: 11 with melphalan alone, and 11 with TNF-alpha and melphalan. Patients possessed advanced tumor burden with a mean percentage of hepatic replacement of $25 \%$. The overall response rate in 21 patients was $62 \%$ including 2 radiographic complete responses (9.5\%) and 11 partial responses (52\%). The overall median duration of response was 9 months (range 5-50) and was significantly longer in those treated with TNF than without (14 versus 6 months, respectively). This study points to the importance of TNF-alpha in isolated perfusion protocols [96]. Interestingly, in animal models of IHP, correlations are seen between degree of tumor vascularization and tumor reduction, further suggesting that TNF-alpha mechanistically targets the tumor endothelium [97].

\section{Extracorporeal removal of soluble TNF-alpha receptors as a therapeutic}

In the light of their pro-tumor activity, the removal of soluble TNF-Rs seemed to be a logical step toward the development of an effective anti-cancer therapy [52, 
53]. To test the anti-cancer effects of removing inhibitory sTNF-Rs, Immunicom, Inc. conducted a preclinical canine cancer study using a novel single-chain TNF-alphabased affinity column (a.k.a. "LW-02" device) used in combination with a Terumo Optia apheresis system. The blood from catheterized canine patients was pumped into the Optia system which separated the patients' plasma from their cells by continuous centrifugation. During each treatment, an LW-02 affinity column device was placed into the plasma flow line to capture sTNF-Rs from the patient's plasma which was then recombined with the previously separated cells and returned to the patient. Most of the dogs in the trial were stage III or IV patients which had failed standard therapeutic approaches. The results of the study were very encouraging.

Overall, $50-60 \%$ of the patients treated were observed to have either stable disease or partial responses by RECIST Criteria during treatment with one patient having experienced a complete response with clearance of metastases. In over 300 treatments, throughout the study, the LW-02 devices appeared to be safe with no adverse events that were attributable to their use. The quality of life of the patients was effectively maintained during the treatment regimens and a significant life extension was observed based on initial prognoses.

In humans, few treatment options are available for stage IV patients that are unresponsive to standard treatments. Thus, subtractive therapies may be an effective alternative to fill this gap.

There is also potential for its use: (1) In combination therapies with cytotoxic drugs that induce or are enhanced in combination TNF-alpha (Table 1); (2) With immunotherapeutics such as antibodies to PD1, PDL1 or CTLA4; and/or (3) In combination with cytokines, such as IFNg and TNF-alpha [73]. It is speculated that the removal of TNF receptors may increase the effectiveness of TNF-alpha administration while decreasing systemic toxicity.

Table 1 Table of cytotoxic drugs that induce TNF-alpha and are enhanced in their activity with TNF-alpha

\begin{tabular}{lll}
\hline Anti-neoplastic drug & Class & $\begin{array}{l}\text { Enhanced } \\
\text { with TNF- } \\
\text { alpha }\end{array}$ \\
\hline Paclitaxel (taxol) & Diterpene & Yes \\
Doxorubicin & Anthracycline & Yes \\
Cytoxan & Cyclophosphamide & Yes \\
Gemcitabine & Nucleoside analogue & Yes \\
Cytarabine & Nucleoside analogue & Yes \\
Melphalan & Nitrogen mustard & Yes \\
\hline
\end{tabular}

\section{Conclusion}

TNF-alpha is a fundamental molecule in various aspects of immunology. Original efforts at therapeutic applications failed due to systemic toxicities. In the new era of cancer immunotherapy, a promising research direction is augmentation of endogenous TNF-alpha activity through removal of its soluble receptors.

\section{Abbreviations \\ CTLA-4: cytotoxic T lymphocyte antigen-4; IFN: interferon; IL-6: interleukin-6; ILP: isolated limb perfusion; PD-L1: programmed death ligand-1.}

\section{Authors' contributions}

SFJ, TEI, SMP, SK, FMM, ARE and AJ collaborated on advancing the concepts contained in this manuscript, performed literature review, wrote the manuscript and proofread the manuscript. All authors read and approved the final manuscript.

\section{Author details}

${ }^{1}$ Immunicom, Inc., San Diego, CA, USA. ${ }^{2}$ Immune Advisors LLC, La Jolla, San Diego, CA, USA. ${ }^{3}$ John Wayne Cancer Institute and Pacific Neuroscience Institute, Santa Monica, CA, USA. ${ }^{4}$ CHIPSA Hospital, Baja California, Mexico.

\section{Acknowledgements}

None.

\section{Competing interests}

SFJ, SMP, AJ are employees of Immunicom, Inc, a clinical stage medical technology company developing revolutionary non-pharmaceutical approaches for treating cancer and autoimmune diseases. SK and FMM are advisors to Immunicom, Inc.

Availability of data and materials Not applicable.

Consent for publication

Not applicable.

Ethics approval and consent to participate

Not applicable.

Funding

Not applicable.

\section{Publisher's Note}

Springer Nature remains neutral with regard to jurisdictional claims in published maps and institutional affiliations.

Received: 7 July 2018 Accepted: 18 August 2018

Published online: 31 August 2018

\section{References}

1. O'Malley WE, Achinstein B, Shear MJ. Journal of the National Cancer Institute, Vol. 29, 1962: Action of bacterial polysaccharide on tumors. II. Damage of sarcoma 37 by serum of mice treated with Serratia marcescens polysaccharide, and induced tolerance. Nutr Rev. 1988;29:389-91.

2. Carswell EA, Old $\sqcup$, Kassel RL, Green S, Fiore N, Williamson B. An endotoxin-induced serum factor that causes necrosis of tumors. Proc Natl Acad Sci USA. 1975:72:3666-70.

3. Pennica D, Nedwin GE, Hayflick JS, Seeburg PH, Derynck R, Palladino MA, Kohr WJ, Aggarwal BB, Goeddel DV. Human tumour necrosis factor: precursor structure, expression and homology to lymphotoxin. Nature. 1984;312:724-9. 
4. Wang AM, Creasey AA, Ladner MB, Lin LS, Strickler J, Van Arsdell JN, Yamamoto R, Mark DF. Molecular cloning of the complementary DNA for human tumor necrosis factor. Science. 1985;228:149-54.

5. Beutler B, Greenwald D, Hulmes JD, Chang M, Pan YC, Mathison J, Ulevitch $\mathrm{R}$, Cerami A. Identity of tumour necrosis factor and the macrophagesecreted factor cachectin. Nature. 1985;316:552-4.

6. Tracey KJ, Wei H, Manogue KR, Fong Y, Hesse DG, Nguyen HT, Kuo GC, Beutler B, Cotran RS, Cerami A, et al. Cachectin/tumor necrosis factor induces cachexia, anemia, and inflammation. J Exp Med. 1988;167:1211-27.

7. Tracey KJ, Morgello S, Koplin B, Fahey TJ 3rd, Fox J, Aledo A, Manogue KR, Cerami A. Metabolic effects of cachectin/tumor necrosis factor are modified by site of production. Cachectin/tumor necrosis factorsecreting tumor in skeletal muscle induces chronic cachexia, while implantation in brain induces predominantly acute anorexia. J Clin Invest. 1990:86:2014-24.

8. Clark IA. Suggested importance of monokines in pathophysiology of endotoxin shock and malaria. Klin Wochenschr. 1982;60:756-8.

9. Clark IA, Virelizier JL, Carswell EA, Wood PR. Possible importance of macrophage-derived mediators in acute malaria. Infect Immun. 1981;32:1058-66.

10. Beutler B, Milsark IW, Cerami AC. Passive immunization against cachectin/ tumor necrosis factor protects mice from lethal effect of endotoxin. Science. 1985;229:869-71.

11. Tracey KJ, Beutler B, Lowry SF, Merryweather J, Wolpe S, Milsark IW, Hariri RJ, Fahey TJ 3rd, Zentella A, Albert JD, et al. Shock and tissue injury induced by recombinant human cachectin. Science. 1986;234:470-4.

12. Black RA, Rauch CT, Kozlosky CJ, Peschon JJ, Slack JL, Wolfson MF, Castner BJ, Stocking KL, Reddy P, Srinivasan S, Nelson N, Boiani N, Schooley KA Gerhart M, Davis R, Fitzner JN, Johnson RS, Paxton RJ, March CJ, Cerretti DP. A metalloproteinase disintegrin that releases tumour-necrosis factoralpha from cells. Nature. 1997;385:729-33.

13. Kriegler M, Perez C, DeFay K, Albert I, Lu SD. A novel form of TNF/cachectin is a cell surface cytotoxic transmembrane protein: ramifications for the complex physiology of TNF. Cell. 1988;53:45-53.

14. Parameswaran N, Patial S. Tumor necrosis factor-alpha signaling in macrophages. Crit Rev Eukaryot Gene Expr. 2010;20:87-103.

15. Ruddle NH, Waksman BH. Cytotoxicity mediated by soluble antigen and lymphocytes in delayed hypersensitivity. 3. Analysis of mechanism. J Exp Med. 1968;128:1267-79.

16. Kolb WP, Granger GA. Lymphocyte in vitro cytotoxicity: characterization of human lymphotoxin. Proc Natl Acad Sci USA. 1968:61:1250-5.

17. Spahn TW, Eugster HP, Fontana A, Domschke W, Kucharzik T. Role of lymphotoxin in experimental models of infectious diseases: potential benefits and risks of a therapeutic inhibition of the lymphotoxin-beta receptor pathway. Infect Immun. 2005;73:7077-88.

18. Aggarwal BB, Gupta SC, Kim JH. Historical perspectives on tumor necrosis factor and its superfamily: 25 years later, a golden journey. Blood. 2012;119:651-65.

19. Vanamee ES, Faustman DL. Structural principles of tumor necrosis factor superfamily signaling. Sci Signal. 2018;11:eaao4910.

20. Bodmer JL, Schneider P, Tschopp J. The molecular architecture of the TNF superfamily. Trends Biochem Sci. 2002;27:19-26.

21. Cabal-Hierro L, Lazo PS. Signal transduction by tumor necrosis factor receptors. Cell Signal. 2012;24:1297-305.

22. Park $\mathrm{YH}$, Jeong MS, Jang SB. Structural insights of homotypic interaction domains in the ligand-receptor signal transduction of tumor necrosis factor (TNF). BMB Rep. 2016:49:159-66.

23. Ham B, Fernandez MC, D'Costa Z, Brodt P. The diverse roles of the TNF axis in cancer progression and metastasis. Trends Cancer Res. 2016;11:1-27.

24. Marchetti L, Klein M, Schlett K, Pfizenmaier K, Eisel UL. Tumor necrosis factor (TNF)-mediated neuroprotection against glutamate-induced excitotoxicity is enhanced by $\mathrm{N}$-methyl-D-aspartate receptor activation. Essential role of a TNF receptor 2-mediated phosphatidylinositol 3-kinasedependent NF-kappa B pathway. J Biol Chem. 2004;279:32869-81.

25. Brenner D, Blaser H, MakTW. Regulation of tumour necrosis factor signalling: live or let die. Nat Rev Immunol. 2015;15:362-74.

26. Cowburn AS, Deighton J, Walmsley SR, Chilvers ER. The survival effect of TNF-alpha in human neutrophils is mediated via NF-kappa B-dependent IL-8 release. Eur J Immunol. 2004;34:1733-43.
27. Hamid T, Gu Y, Ortines RV, Bhattacharya C, Wang G, Xuan YT, Prabhu SD. Divergent tumor necrosis factor receptor-related remodeling responses in heart failure: role of nuclear factor-kappaB and inflammatory activation. Circulation. 2009;119:1386-97.

28. Torrey H, Butterworth J, Mera T, Okubo Y, Wang L, Baum D, Defusco A, Plager S, Warden S, Huang D, Vanamee E, Foster R, Faustman DL. Targeting TNFR2 with antagonistic antibodies inhibits proliferation of ovarian cancer cells and tumor-associated Tregs. Sci Signal. 2017;10:eaaf8608.

29. Hsu H, Xiong J, Goeddel DV. The TNF receptor 1-associated protein TRADD signals cell death and NF-kappa B activation. Cell. 1995:81:495-504.

30. Huang J, Yu S, Ji C, Li J. Structural basis of cell apoptosis and necrosis in TNFR signaling. Apoptosis. 2015;20:210-5.

31. Rothe M, Sarma V, Dixit VM, Goeddel DV. TRAF2-mediated activation of NF-kappa B by TNF receptor 2 and CD40. Science. 1995;269:1424-7.

32. Grell $M$, Wajant H, Zimmermann G, Scheurich P. The type 1 receptor (CD120a) is the high-affinity receptor for soluble tumor necrosis factor. Proc Natl Acad Sci USA. 1998;95:570-5.

33. Grell M, Douni E, Wajant H, Lohden M, Clauss M, Maxeiner B, Georgopoulos S, Lesslauer W, Kollias G, Pfizenmaier K, Scheurich P. The transmembrane form of tumor necrosis factor is the prime activating ligand of the $80 \mathrm{kDa}$ tumor necrosis factor receptor. Cell. 1995;83:793-802.

34. Deng J, Zhao X, Rong L, Li X, Liu X, Qin Z. TNFR-1 on tumor cells contributes to the sensitivity of fibrosarcoma to chemotherapy. Protein Cell. 2013:4:393-401.

35. Huang P, Rani MR, Ahluwalia MS, Bae E, Prayson RA, Weil RJ, Nowacki AS, Hedayat H, Sloan AE, Lathia JD, Rich JN, Tipps R, Gladson CL. Endothelia expression of TNF receptor-1 generates a proapoptotic signal inhibited by integrin alpha6beta1 in glioblastoma. Cancer Res. 2012;72:1428-37.

36. Chopra M, Biehl M, Steinfatt T, Brandl A, Kums J, Amich J, Vaeth M, Kuen J, Holtappels R, Podlech J, Mottok A, Kraus S, Jordan-Garrote AL, Bauerlein CA, Brede C, Ribechini E, Fick A, Seher A, Polz J, Ottmuller KJ, Baker J, Nishikii H, Ritz M, Mattenheimer K, Schwinn S, Winter T, Schafer V, Krappmann S, Einsele H, Muller TD, Reddehase MJ, Lutz MB, Mannel DN, Berberich-Siebelt F, Wajant H, Beilhack A. Exogenous TNFR2 activation protects from acute GvHD via host T reg cell expansion. J Exp Med. 2016;213:1881-900

37. Okubo Y, Torrey H, Butterworth J, Zheng H, Faustman DL. Treg activation defect in type 1 diabetes: correction with TNFR2 agonism. Clin Transl Immunol. 2016;5:e56.

38. Polz J, Remke A, Weber S, Schmidt D, Weber-Steffens D, Pietryga-Krieger A, Muller N, Ritter U, Mostbock S, Mannel DN. Myeloid suppressor cells require membrane TNFR2 expression for suppressive activity. Immun Inflamm Dis. 2014:2:121-30.

39. Cui LF, Guo XJ, Wei J, Liu FF, Fan Y, Lang RG, Gu F, Zhang XM, Fu L. Overexpression of TNF-alpha and TNFRII in invasive micropapillary carcinoma of the breast: clinicopathological correlations. Histopathology. 2008;53:381-8

40. Yang F, Zhao Z, Zhao N. Clinical implications of tumor necrosis factor receptor 2 in breast cancer. Oncol Lett. 2017;14:2393-8.

41. Van Hauwermeiren F, Vandenbroucke RE, Grine L, Puimege L, Van Wonterghem E, Zhang H, Libert C. Antisense oligonucleotides against TNFR1 prevent toxicity of TNF/IFNgamma treatment in mouse tumor models. Int J Cancer. 2014;135:742-50.

42. Sasi SP, Bae S, Song J, Perepletchikov A, Schneider D, Carrozza J, Yan X, Kishore R, Enderling H, Goukassian DA. Correction: Therapeutic Non-toxic doses of tnf induce significant regression in TNFR2-p75 knockdown lewis lung carcinoma tumor implants. PLoS ONE. 2015;10:e0144213.

43. Nguyen DX, Ehrenstein MR. Anti-TNF drives regulatory T cell expansion by paradoxically promoting membrane TNF-TNF-RIl binding in rheumatoid arthritis. J Exp Med. 2016;213:1241-53.

44. Loetscher H, Gentz R, Zulauf M, Lustig A, Tabuchi H, Schlaeger EJ, Brockhaus M, Gallati H, Manneberg M, Lesslauer W. Recombinant 55-kDa tumor necrosis factor (TNF) receptor. Stoichiometry of binding to TNF alpha and TNF beta and inhibition of TNF activity. J Biol Chem. 1991;266:18324-9.

45. Deng M, Loughran PA, Zhang L, Scott MJ, Billiar TR. Shedding of the tumor necrosis factor (TNF) receptor from the surface of hepatocytes during sepsis limits inflammation through cGMP signaling. Sci Signal. 2015;8:ra11.

46. Chanthaphavong RS, Loughran PA, Lee TY, Scott MJ, Billiar TR. A role for CGMP in inducible nitric-oxide synthase (iNOS)-induced tumor necrosis 
factor (TNF) alpha-converting enzyme (TACE/ADAM17) activation, translocation, and TNF receptor 1 (TNFR1) shedding in hepatocytes. J Biol Chem. 2012;287:35887-98.

47. Aderka D, Sorkine P, Abu-Abid S, Lev D, Setton A, Cope AP, Wallach D, Klausner J. Shedding kinetics of soluble tumor necrosis factor (TNF) receptors after systemic TNF leaking during isolated limb perfusion. Relevance to the pathophysiology of septic shock. J Clin Invest. 1998;101:650-9.

48. Krippner-Heidenreich A, Tubing F, Bryde S, Willi S, Zimmermann G, Scheurich P. Control of receptor-induced signaling complex formation by the kinetics of ligand/receptor interaction. J Biol Chem. 2002;277:44155-63.

49. Loetscher H, Stueber D, Banner D, Mackay F, Lesslauer W. Human tumor necrosis factor alpha (TNF alpha) mutants with exclusive specificity for the 55-kDa or 75-kDa TNF receptors. J Biol Chem. 1993;268:26350-7.

50. Nakamura S, Kato A, Masegi T, Fukuoka M, Kitai K, Ogawa H, Ichikawa Y, Maeda M, Watanabe N, Kohgo Y, et al. A novel recombinant tumor necrosis factor-alpha mutant with increased anti-tumor activity and lower toxicity. Int J Cancer. 1991:48:744-8.

51. Aderka D, Englemann H, Hornik V, Skornick Y, Levo Y, Wallach D, Kushtai G. Increased serum levels of soluble receptors for tumor necrosis factor in cancer patients. Cancer Res. 1991;51:5602-7.

52. Selinsky CL, Boroughs KL, Halsey WA Jr, Howell MD. Multifaceted inhibition of anti-tumour immune mechanisms by soluble tumour necrosis factor receptor type I. Immunology. 1998:94:88-93.

53. Selinsky CL, Howell MD. Soluble tumor necrosis factor receptor type I enhances tumor development and persistence in vivo. Cell Immunol. 2000;200:81-7.

54. Nie H, Zheng Y, Li R, Guo TB, He D, Fang L, Liu X, Xiao L, Chen X, Wan B, Chin YE, Zhang JZ. Phosphorylation of FOXP3 controls regulatory T cell function and is inhibited by TNF-alpha in rheumatoid arthritis. Nat Med. 2013:19:322-8

55. Valencia X, Stephens G, Goldbach-Mansky R, Wilson M, Shevach EM, Lipsky PE. TNF downmodulates the function of human CD4+ CD25hi T-regulatory cells. Blood. 2006;108:253-61.

56. Hoving S, Seynhaeve AL, van Tiel ST, aan de Wiel-Ambagtsheer G, de Bruijn EA, Eggermont AM, ten Hagen TL. Early destruction of tumor vasculature in tumor necrosis factor-alpha-based isolated limb perfusion is responsible for tumor response. Anticancer Drugs. 2006;17:949-59.

57. Mackay F, Loetscher H, Stueber D, Gehr G, Lesslauer W. Tumor necrosis factor alpha (TNF-alpha)-induced cell adhesion to human endothelial cells is under dominant control of one TNF receptor type, TNF-R55. J Exp Med. 1993:177:1277-86.

58. Lejeune FJ, Lienard D, Matter M, Ruegg C. Efficiency of recombinant human TNF in human cancer therapy. Cancer Immun Arch. 2006:6:6.

59. Qiao Y, Huang X, Nimmagadda S, Bai R, Staedtke V, Foss CA, Cheong I, Holdhoff M, Kato Y, Pomper MG, Riggins GJ, Kinzler KW, Diaz LA Jr, Vogelstein B, Zhou S. A robust approach to enhance tumor-selective accumulation of nanoparticles. Oncotarget. 2011;2:59-68.

60. Kratochvill F, Neale G, Haverkamp JM, Van de Velde LA, Smith AM, Kawauchi D, McEvoy J, Roussel MF, Dyer MA, Qualls JE, Murray PJ. TNF counterbalances the emergence of M2 tumor macrophages. Cell Rep. 2015;12:1902-14.

61. Marino MW, Dunn A, Grail D, Inglese M, Noguchi Y, Richards E, Jungbluth A, Wada H, Moore M, Williamson B, Basu S, Old LJ. Characterization of tumor necrosis factor-deficient mice. Proc Natl Acad Sci USA. 1997;94:8093-8.

62. Sethi G, Sung B, Aggarwal BB. TNF: a master switch for inflammation to cancer. Front Biosci. 2008;13:5094-107.

63. Ardestani S, Deskins DL, Young PP. Membrane TNF-alpha-activated programmed necrosis is mediated by Ceramide-induced reactive oxygen species. J Mol Signal. 2013;8:12.

64. Ardestani S, Li B, Deskins DL, Wu H, Massion PP, Young PP. Membrane versus soluble isoforms of TNF-alpha exert opposing effects on tumor growth and survival of tumor-associated myeloid cells. Cancer Res. 2013;73:3938-50.

65. Waetzig GH, Rosenstiel P, Arlt A, Till A, Brautigam K, Schafer H, Rose-John $\mathrm{S}$, Seegert D, Schreiber S. Soluble tumor necrosis factor (TNF) receptor-1 induces apoptosis via reverse TNF signaling and autocrine transforming growth factor-beta1. FASEB J. 2005;19:91-3.

66. Nedospasov SA, Grivennikov SI, Kuprash DV. Physiologic roles of members of the TNF and TNF receptor families as revealed by knockout models. In: Fantuzzi G, editor. Cytokine Knockouts. 2nd ed. New York: Humana Press; 2002. p. 439-60.

67. Kottke T, Evgin L, Shim KG, Rommelfanger D, Boisgerault N, Zaidi S, Diaz RM, Thompson J, llett E, Coffey M, Selby P, Pandha H, Harrington K, Melcher A, Vile R. Subversion of NK-cell and TNFalpha immune surveillance drives tumor recurrence. Cancer Immunol Res. 2017;5:1029-45.

68. Harrison ML, Obermueller E, Maisey NR, Hoare S, Edmonds K, Li NF, Chao D, Hall K, Lee C, Timotheadou E, Charles K, Ahern R, King DM, Eisen T, Corringham R, DeWitte M, Balkwill F, Gore M. Tumor necrosis factor alpha as a new target for renal cell carcinoma: two sequential phase II trials of infliximab at standard and high dose. J Clin Oncol. 2007;25:4542-9.

69. Brown ER, Charles KA, Hoare SA, Rye RL, Jodrell DI, Aird RE, Vora R, Prabhakar U, Nakada M, Corringham RE, DeWitte M, Sturgeon C, Propper D, Balkwill FR, Smyth JF. A clinical study assessing the tolerability and biological effects of infliximab, a TNF-alpha inhibitor, in patients with advanced cancer. Ann Oncol. 2008;19:1340-6.

70. Madhusudan S, Foster M, Muthuramalingam SR, Braybrooke JP, Wilner S, Kaur K, Han C, Hoare S, Balkwill F, Talbot DC, Ganesan TS, Harris AL. A phase Il study of etanercept (Enbrel), a tumor necrosis factor alpha inhibitor in patients with metastatic breast cancer. Clin Cancer Res. 2004;10:6528-34

71. Keystone EC, Kavanaugh AF, Sharp JT, Tannenbaum H, Hua Y, Teoh LS, Fischkoff SA, Chartash EK. Radiographic, clinical, and functional outcomes of treatment with adalimumab (a human anti-tumor necrosis factor monoclonal antibody) in patients with active rheumatoid arthritis receiving concomitant methotrexate therapy: a randomized, placebo-controlled, 52-week trial. Arthritis Rheum. 2004;50:1400-11.

72. Mercer LK, Green AC, Galloway JB, Davies R, Lunt M, Dixon WG, Watson $\mathrm{KD}$, Symmons DP, Hyrich KL, British Society for Rheumatology Biologics Register Control Centre, British Society for Rheumatology Biologics, R. The influence of anti-TNF therapy upon incidence of keratinocyte skin cancer in patients with rheumatoid arthritis: longitudinal results from the British Society for Rheumatology Biologics Register. Ann Rheum Dis. 2012;71:869-74.

73. Zhang B, Karrison T, Rowley DA, Schreiber H. IFN-gamma- and TNFdependent bystander eradication of antigen-loss variants in established mouse cancers. J Clin Invest. 2008;118:1398-404.

74. Brett J, Gerlach H, Nawroth P, Steinberg S, Godman G, Stern D. Tumor necrosis factor/cachectin increases permeability of endothelial cell monolayers by a mechanism involving regulatory $\mathrm{G}$ proteins. J Exp Med. 1989;169:1977-91.

75. Rothstein JL, Lint TF, Schreiber H. Tumor necrosis factor/cachectin Induction of hemorrhagic necrosis in normal tissue requires the fifth component of complement (C5). J Exp Med. 1988;168:2007-21.

76. Shenoi MM, Itis I, Choi J, Koonce NA, Metzger GJ, Griffin RJ, Bischof JC. Nanoparticle delivered vascular disrupting agents (VDAs): use of TNFalpha conjugated gold nanoparticles for multimodal cancer therapy. Mol Pharm. 2013;10:1683-94.

77. Dondossola E, Dobroff AS, Marchio S, Cardo-Vila M, Hosoya H, Libutti SK, Corti A, Sidman RL, Arap W, Pasqualini R. Self-targeting of TNF-releasing cancer cells in preclinical models of primary and metastatic tumors. Proc Natl Acad Sci USA. 2016;113:2223-8.

78. Wu TH, Pabin CN, Qin Z, Blankenstein T, Philip M, Dignam J, Schreiber K, Schreiber $\mathrm{H}$. Long-term suppression of tumor growth by TNF requires a Stat1- and IFN regulatory factor 1-dependent IFN-gamma pathway but not IL-12 or IL-18. J Immunol. 2004;172:3243-51.

79. Roberts NJ, Zhou S, Diaz LA Jr, Holdhoff M. Systemic use of tumor necrosis factor alpha as an anticancer agent. Oncotarget. 2011;2:739-51.

80. Kimura K, Taguchi T, Urushizaki I, Ohno R, Abe O, Furue H, Hattori T, Ichihashi $\mathrm{H}$, Inoguchi K, Majima H, et al. Phase I study of recombinant human tumor necrosis factor. Cancer Chemother Pharmacol. 1987;20:223-9.

81. Creaven PJ, Plager JE, Dupere S, Huben RP, Takita H, Mittelman A, Proefrock A. Phase I clinical trial of recombinant human tumor necrosis factor. Cancer Chemother Pharmacol. 1987;20:137-44.

82. Budd GT, Green S, Baker LH, Hersh EP, Weick JK, Osborne CK. A Southwest Oncology Group phase II trial of recombinant tumor necrosis factor in metastatic breast cancer. Cancer. 1991;68:1694-5.

83. Whitehead RP, Fleming T, Macdonald JS, Goodman PJ, Neefe J, Braun TJ, Swinnen $L$, Hersh EM. A phase II trial of recombinant tumor necrosis factor in patients with metastatic colorectal adenocarcinoma: a Southwest Oncology Group study. J Biol Response Modif. 1990;9:588-91. 
84. Brown TD, Goodman P, Fleming T, Macdonald JS, Hersh EM, Braun TJ. A phase II trial of recombinant tumor necrosis factor in patients with adenocarcinoma of the pancreas: a Southwest Oncology Group study. J Immunother. 1991;10:376-8.

85. Muggia FM, Brown TD, Goodman PJ, Macdonald JS, Hersh EM, Fleming TR, Leichman L. High incidence of coagualopathy in phase II studies of recombinant tumor necrosis factor in advanced pancreatic and gastric cancers. Anticancer Drugs. 1992;3:211-7.

86. Kahn JO, Kaplan LD, Volberding PA, Ziegler JL, Crowe S, Saks SR, Abrams DI. Intralesional recombinant tumor necrosis factor-alpha for AIDS-associated Kaposi's sarcoma: a randomized, double-blind trial. J Acquir Immune Defic Syndr. 1989;2:217-23.

87. Albini A, Barillari G, Benelli R, Gallo RC, Ensoli B. Angiogenic properties of human immunodeficiency virus type 1 Tat protein. Proc Natl Acad Sci USA. 1995;92:4838-42.

88. Kawai T, Satomi N, Sato N, Sakurai A, Haranaka K, Goto T, Suzuki M. Necrotizing activity of tumor necrosis factor: histopathological investigation using Meth A sarcoma and granulation tissue. Virchows Arch B Cell Pathol Incl Mol Pathol. 1987;53:353-8.

89. Watanabe $N$, Niitsu $Y$, Umeno H, Kuriyama H, Neda H, Yamauchi N, Maeda M, Urushizaki I. Toxic effect of tumor necrosis factor on tumor vasculature in mice. Cancer Res. 1988;48:2179-83.

90. Renard N, Nooijen PT, Schalkwijk L, De Waal RM, Eggermont AM, Lienard D, Kroon BB, Lejeune FJ, Ruiter DJ. WWF release and platelet aggregation in human melanoma after perfusion with TNF alpha. J Pathol. 1995; 176:279-87.
91. Manusama ER, Nooijen PT, Stavast J, Durante NM, Marquet RL, Eggermont AM. Synergistic antitumour effect of recombinant human tumour necrosis factor alpha with melphalan in isolated limb perfusion in the rat. $\mathrm{Br} J$ Surg. 1996:83:551-5.

92. Manusama ER, Stavast J, Durante NM, Marquet RL, Eggermont AM. Isolated limb perfusion with TNF alpha and melphalan in a rat osteosarcoma model: a new anti-tumour approach. Eur J Surg Oncol. 1996;22:152-7.

93. Shimomura K, Manda T, Mukumoto S, Kobayashi K, Nakano K, Mori J. Recombinant human tumor necrosis factor-alpha: thrombus formation is a cause of anti-tumor activity. Int J Cancer. 1988;41:243-7.

94. van Horssen R, Ten Hagen TL, Eggermont AM. TNF-alpha in cancer treatment: molecular insights, antitumor effects, and clinical utility. Oncologist. 2006;11:397-408

95. Alexander HR Jr, Bartlett DL, Libutti SK. Current status of isolated hepatic perfusion with or without tumor necrosis factor for the treatment of unresectable cancers confined to liver. Oncologist. 2000:5:416-24.

96. Alexander HR, Libutti SK, Bartlett DL, Puhlmann M, Fraker DL, Bachenheimer LC. A phase I-II study of isolated hepatic perfusion using melphalan with or without tumor necrosis factor for patients with ocular melanoma metastatic to liver. Clin Cancer Res. 2000;6:3062-70.

97. van Etten B, de Vries MR, van IJken MG, Lans TE, Guetens G, Ambagtsheer G, van Tiel ST, de Boeck G, de Bruijn EA, Eggermont AM, ten Hagen TL. Degree of tumour vascularity correlates with drug accumulation and tumour response upon TNF-alpha-based isolated hepatic perfusion. $\mathrm{Br}$ J Cancer. 2003:88:314-9.
Ready to submit your research? Choose BMC and benefit from:

- fast, convenient online submission

- thorough peer review by experienced researchers in your field

- rapid publication on acceptance

- support for research data, including large and complex data types

- gold Open Access which fosters wider collaboration and increased citations

- maximum visibility for your research: over $100 \mathrm{M}$ website views per year

At BMC, research is always in progress.

Learn more biomedcentral.com/submissions 